\title{
Three species of butterflies new for the North Aegean Island of Lemnos (Greece)
}

\author{
Mario Langourov ${ }^{1}$, Nikolay Simov ${ }^{2}$, Stanislav Abadjiev $^{3}$ \\ National Museum of Natural History, Bulgarian Academy of Sciences, 1 Tsar Osvoboditel Blvd, 1000 Sofia, Bulgaria \\ (1) langourov@nmnhs.com; https://orcid.org/0000-0001-6756-3420 \\ (2)simov@nmnhs.com; https://orcid.org/0000-0003-1626-2964 \\ (3) abadjiev@nmnhs.com; https://orcid.org/0000-0001-9106-1754
}

\begin{abstract}
The paper presents results of a brief entomological surveys carried out in the southern parts of Lemnos Island in 2016, 2017 and 2019. It includes a list of 14 recorded species of butterflies, three of which are new for the island.
\end{abstract}

Keywords: butterfly, distribution, Lepidoptera, Lemnos, new records

\section{Introduction}

The first information for the butterflies of the Lemnos [Límnos] Island is found in the earliest works on Greek Lepidoptera fauna by Mathew (1898) and Rebel (1934, 1937). The detailed work of Olivier (1988) includes 31 species, 13 of which are new for the island. Thirteen years later another special article devoted to the island's butterfly fauna has followed. It also includes 31 species, four of which are an addition (Coutsis, 2001). Altogether 33 species of butterflies are known from the island till now, with records of two of these 33 species, Coenonympha pamphilus (Linnaeus, 1758) and $\mathrm{La}$ siommata maera (Linnaeus, 1758), being questionable.

\section{Results}

During three visits of Lemnos in 2016, 2017 and 2019 some butterfly species has been observed and photographed. Three of them are new for the island's faunaPelopidas thrax (Hübner, [1821]), Cacyreus marshalli Butler, 1898, Danaus chrysippus (Linnaeus, 1758).
The species are listed in taxonomical order following the nomenclature of Tshikolovets (2011).

The list of localities contains the relevant toponyms, a short description of the habitat, altitude, coordinates and dates of the observations. Localities are arranged from the West to the East (Fig. 1):

[L01] near Myrina; Kastro, $70 \mathrm{~m} ; 39.877844^{\circ} \mathrm{N}$, 25.055000 ${ }^{\circ}$; 05.ix.2016; pseudosteppe with grasses and annuals.

[L02] Moudros; in the village, $15 \mathrm{~m} ; 39.873381^{\circ} \mathrm{N}$, 25.268911 ${ }^{\circ} \mathrm{E}$; 27.viii.2016; gardens and flowerbeds.

[L03] Havouli beach; $5 \mathrm{~m} ; 39.838378^{\circ} \mathrm{N}$, 25.264263 ${ }^{\circ}$ E; 30.viii.2016; Aegean phrygana, dune sclerophyllous scrubs, shrubby formations with Quercus coccifera L., Pinus halepensis Mill.

[L04] near Havouli beach; $34 \mathrm{~m} ; 39.838557^{\circ} \mathrm{N}$, 25.273076 ${ }^{\circ}$; 04.ix.2019; Aegean phrygana, slacks with reedbeds and Tamarix L. (Fig. 2).

[L05] Parthenomitos beach; $3 \mathrm{~m} ; 39.829545^{\circ} \mathrm{N}$, 25.284706 ${ }^{\circ}$; 09. ix.2017; shifting dunes along 
Mario Langourov, Nikolay Simov, Stanislav Abadjiev

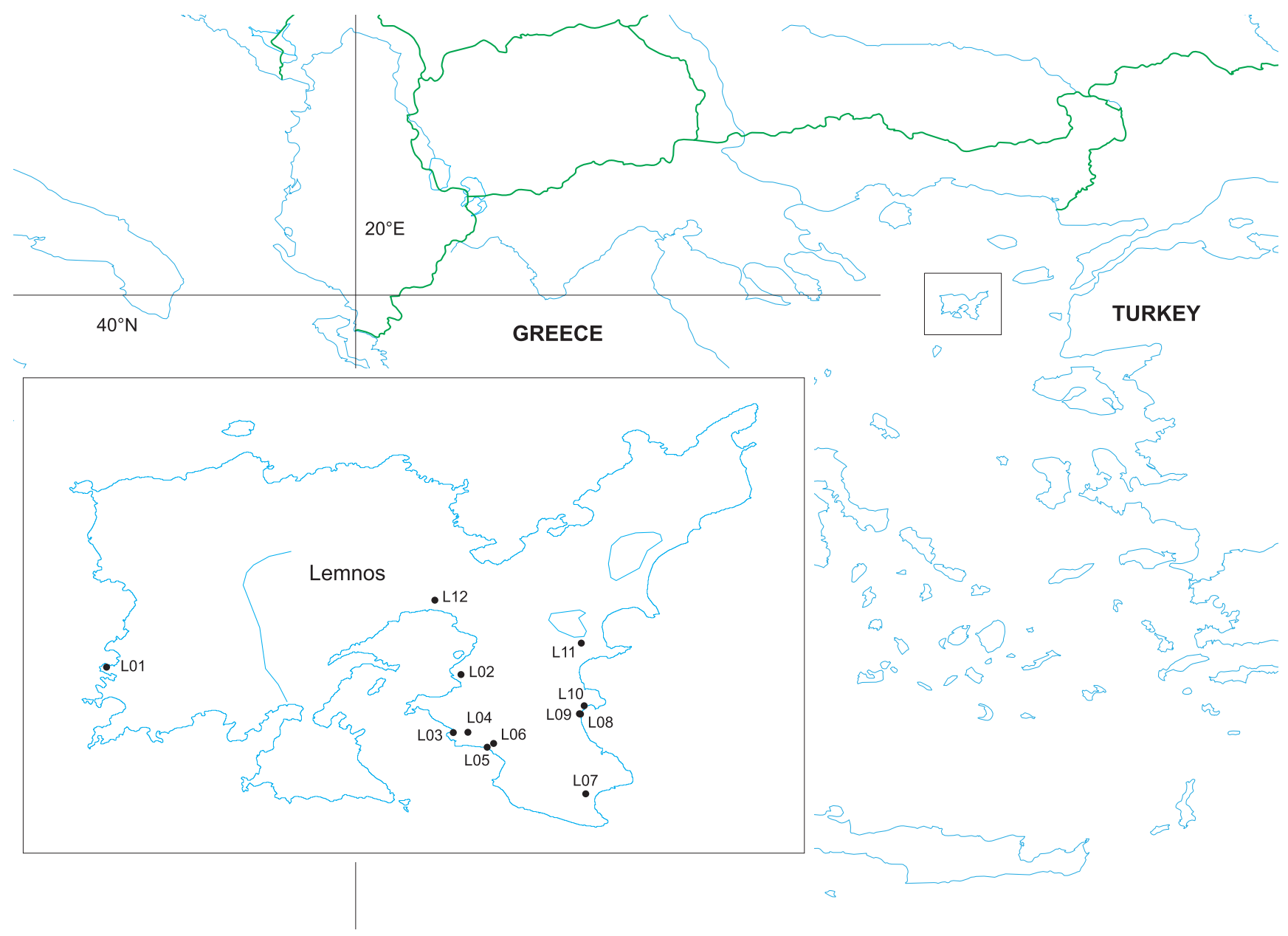

Fig. 1. Map of the localities on the Island of Lemnos, generated with QGIS 3.2 Bonn, Mac OS X version.

the shoreline with Ammophila arenaria (L.) Link, intermittently flowing Mediterranean rivers, Aegean phrygana (Sarcopoterium spinosum (L.) Spach) (Fig. 3).

[L06] near Parthenomitos beach; $25 \mathrm{~m}$; $39.831814^{\circ} \mathrm{N}, 25.288597^{\circ} \mathrm{E}$; 09.ix.2017; Aegean phrygana (Sarcopoterium spinosum) (Fig. 4).

[L07] near Skandali; $23 \mathrm{~m} ; 39.801425^{\circ} \mathrm{N}$, 25.344184 ${ }^{\circ} \mathrm{E}$; 03.ix.2017; sand dunes with $\mathrm{Am}$ mophila arenaria, Pancratium maritimum L., Achillea maritima (L.) Ehrend.\& Y. P. Guo and Centaurea spinosa L., dune sclerophyllous scrubs, Aegean phrygana (Sarcopoterium spinosum).

[L08] Red Rock Beach; $10 \mathrm{~m} ; 39.849708^{\circ} \mathrm{N}$, 25.340398 ${ }^{\circ}$ E; 07.ix.2019; shifting dunes along the shoreline with Ammophila arenaria, dune sclerophyllous scrubs, Aegean phrygana (Sarcopoterium spinosum).

[L09] Red Rock Beach; 8 m; $39.849538^{\circ} \mathrm{N}$, 25.341025 ${ }^{\circ}$; 10.ix.2019; Aegean phrygana, shifting dunes along the shoreline with Ammophila arenaria, dune sclerophyllous scrubs (Fig. 5).

[L10] Ancient Poliochni; $15 \mathrm{~m} ; 39.854548^{\circ} \mathrm{N}$, 25.343265 ${ }^{\circ}$ E; 01.ix.2016; archaeological ruins and garden close to visitors centre of Ancient Poliochni (Fig. 6).

[L11] S shore of Chortarolimni Lake; $5 \mathrm{~m}$; 39.892337 ${ }^{\circ} \mathrm{N}, 25.341514^{\circ} \mathrm{E}$; 01.ix.2016; salt steppes (Limonietalia) and Mediterranean halophilous scrubs (Fig. 7).

[L12] E of Lemnos Airport; $2 \mathrm{~m} ; 39.91769^{\circ} \mathrm{N}$, 25.252093 ${ }^{\circ}$ E; 03.ix.2017; Mediterranean halophilous scrubs (Arthrocnemetalia fruticosae). 
Three species of butterflies new for the North Aegean Island of Lemnos (Greece)

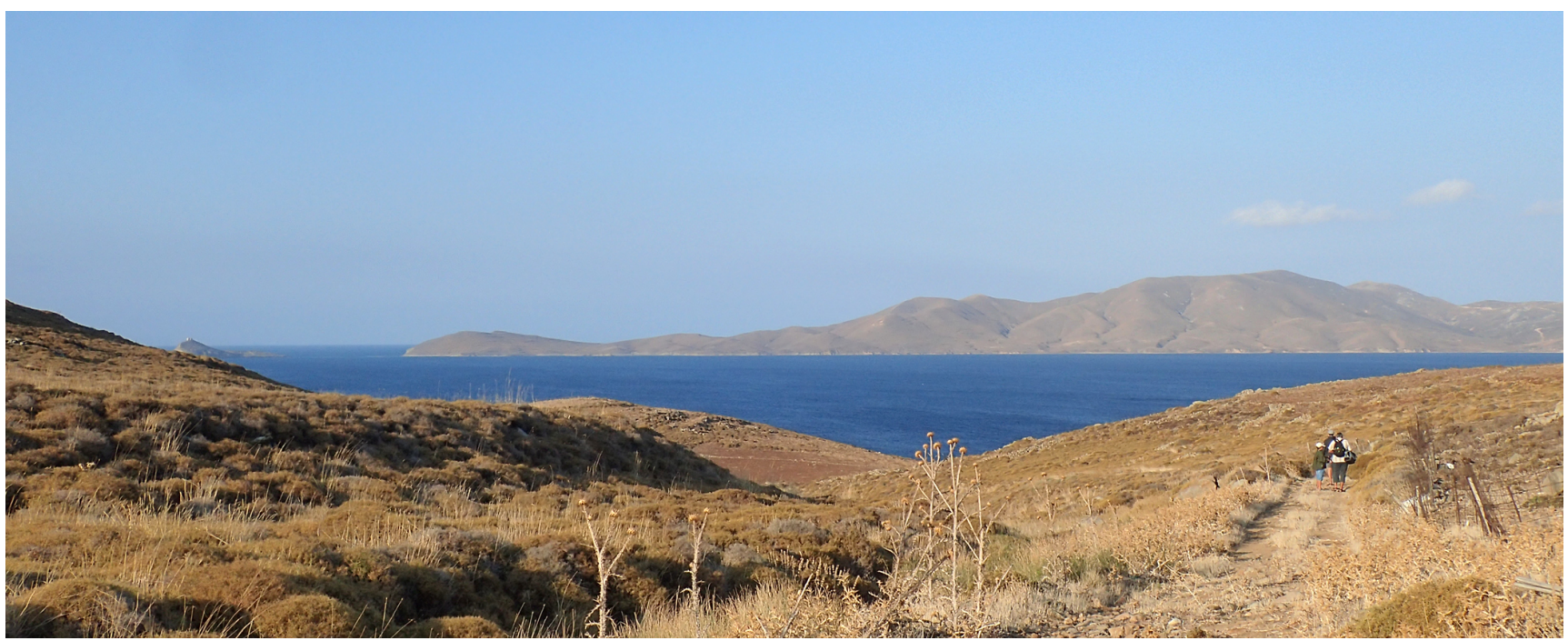

Fig. 2. [L04] near Havouli beach, habitat of Pelopidas thrax.

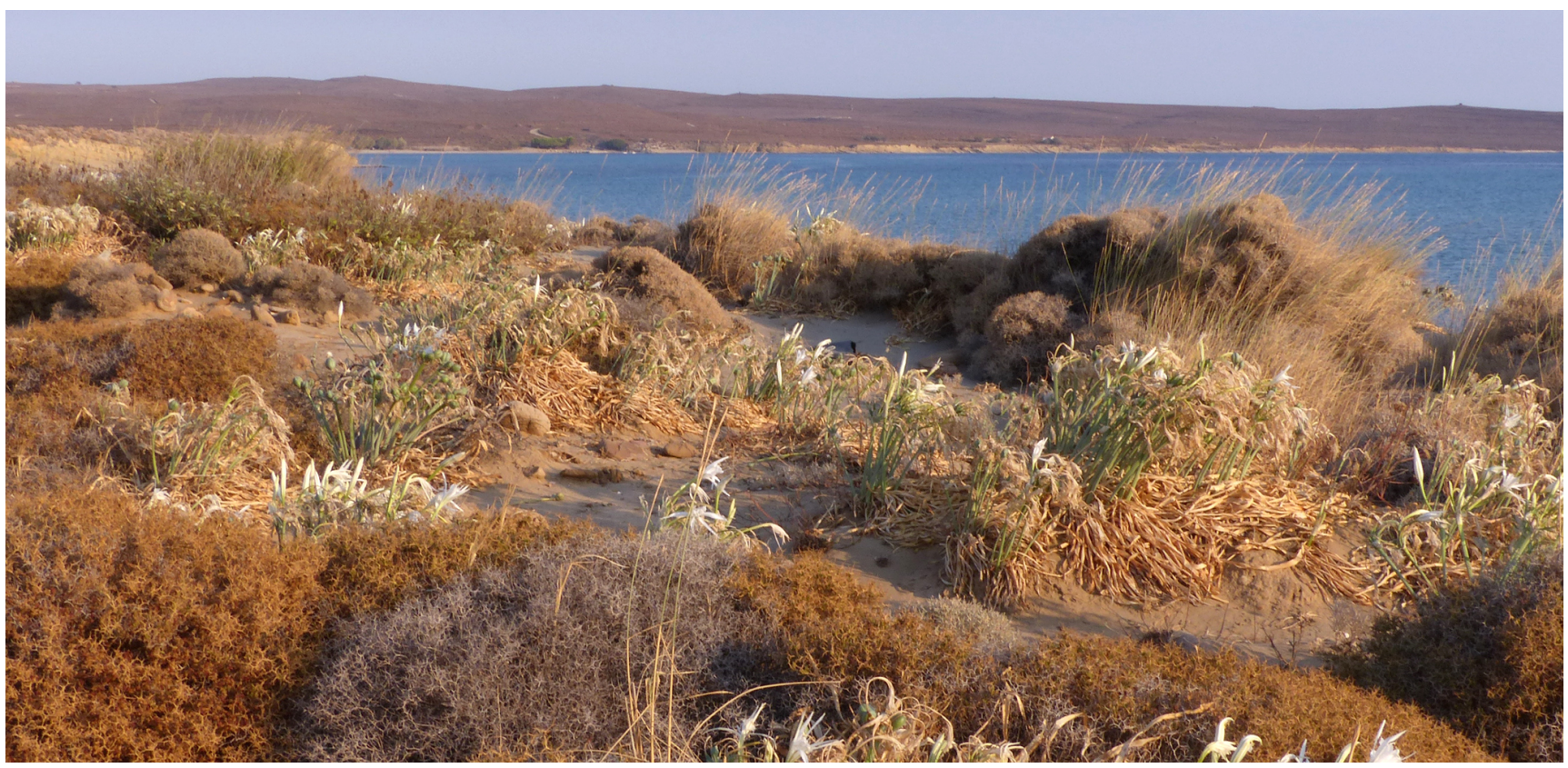

Fig. 3. [L05] Parthenomitos beach, a place where Danaus chrysippus has been observed.

The butterfly species recorded during our visits on the Island of Lemnos are as follows:

\section{Hesperiidae}

Carcharodus alceae (Esper, [1780]): near Parthenomitos beach, 09.ix.2017.

Spialia orbifer (Hübner, [1823]): near Parthenomitos beach, 09.ix.2017.
Pelopidas thrax (Hübner, [1821]): near Havouli beach, 04.ix.2019 (Fig. 8). P. thrax ranges from the eastern Mediterranean to Africa and across subtropical and tropical Asia to Indonesia. In the eastern part of the Aegean Sea it is previously known only from Dodecanese Islands (Samos, Kos, Rhodes) - Cuvelier (2009), Cuvelier \& Mølgaard (2012). The species is also known from the Turkish coast (Hesselbarth et al., 1995). This species is multivoltine - usually from April 
Mario Langourov, Nikolay Simov, Stanislav Abadjiev

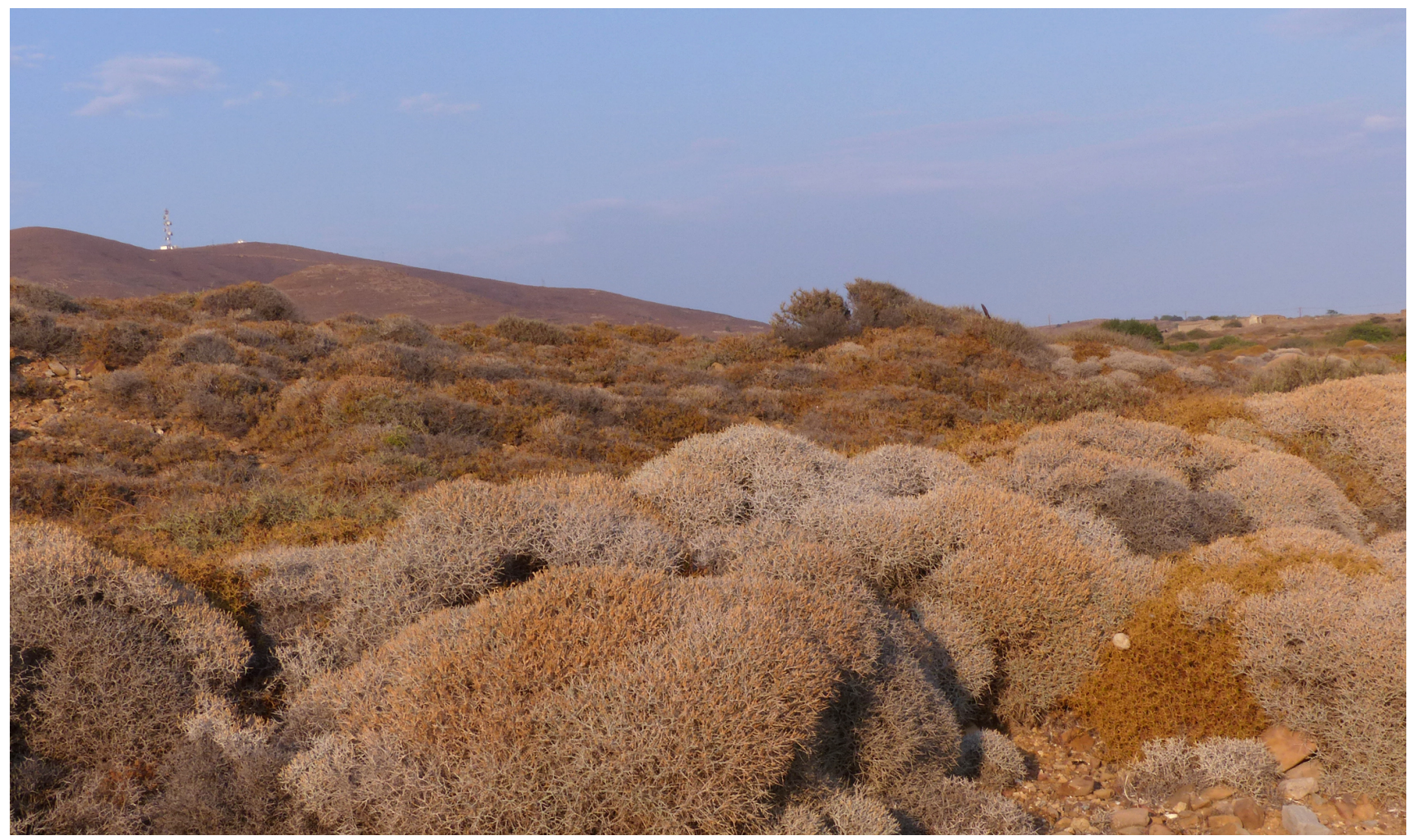

Fig. 4. [L06] near Parthenomitos beach, habitat of Gegenes nostrodamus, Spialia orbifer, Carcharodus alceae, Maniola jurtina.

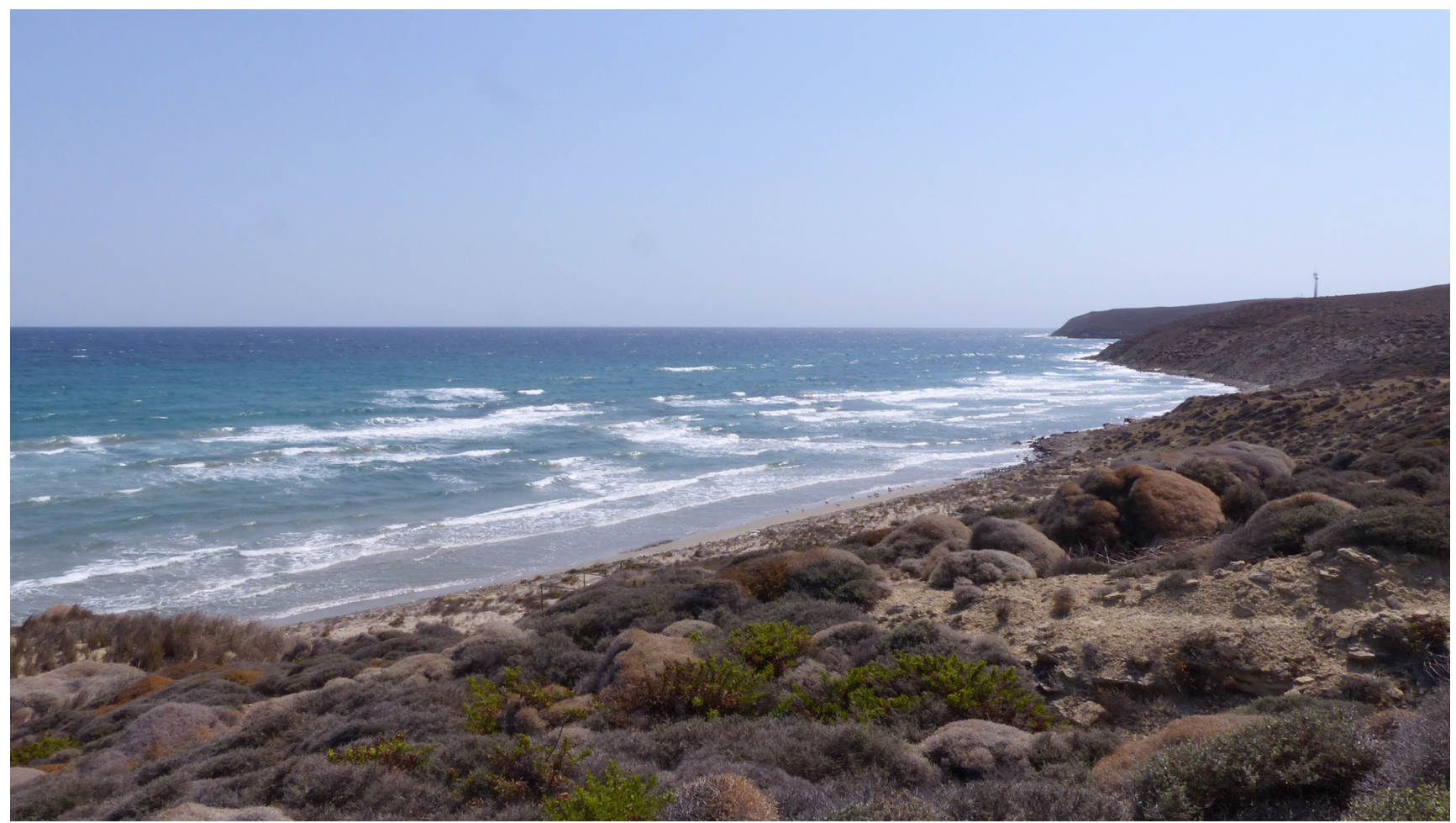

Fig. 5. [L09] Red Rock Beach, a place where Danaus chrysippus has been observed. 
Three species of butterflies new for the North Aegean Island of Lemnos (Greece)

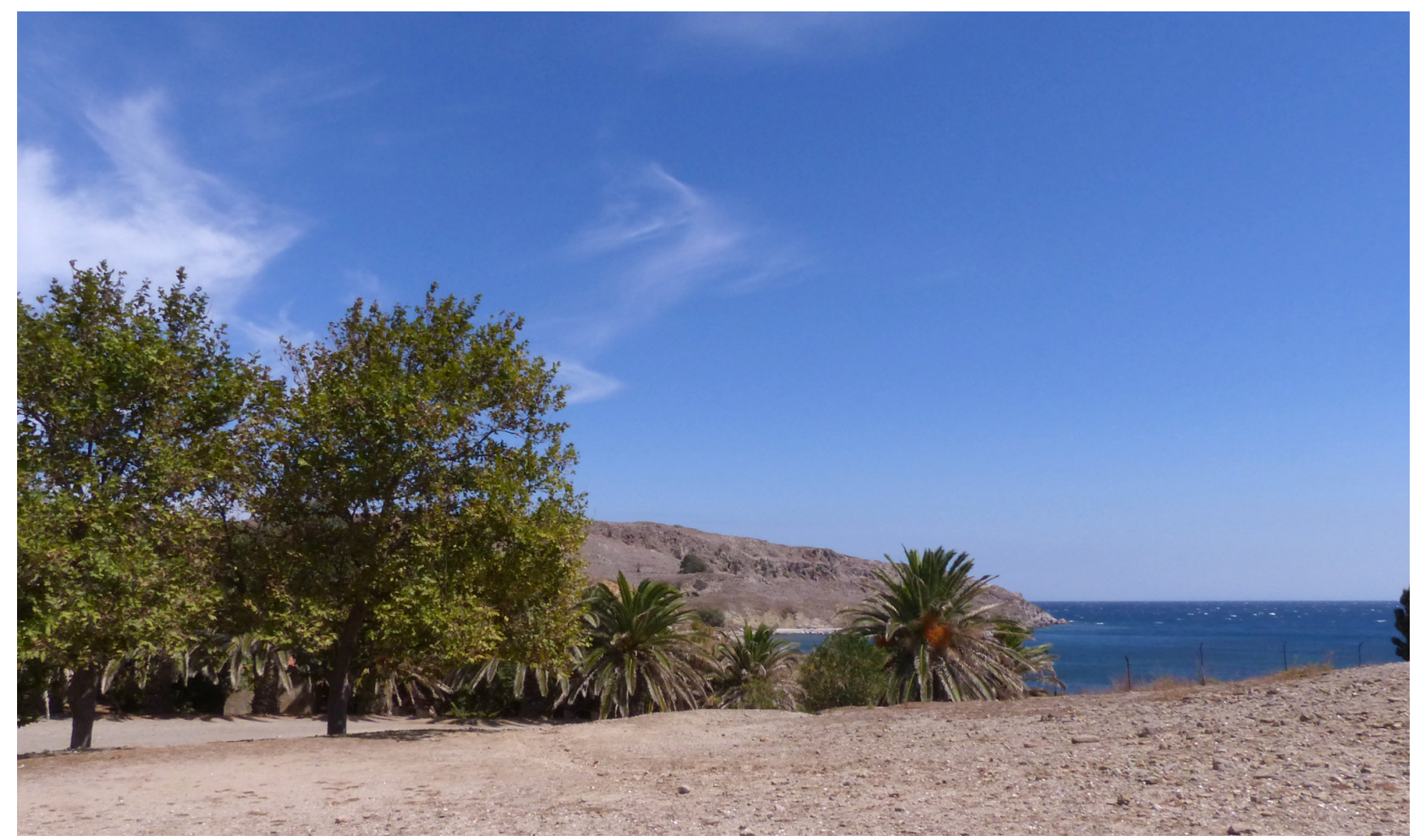

Fig. 6. [L10] Ancient Poliochni, habitat of Lampides boeticus, Leptotes pirithous, Lycaena phleas, Vanessa atalanta, Argynnis pandora.

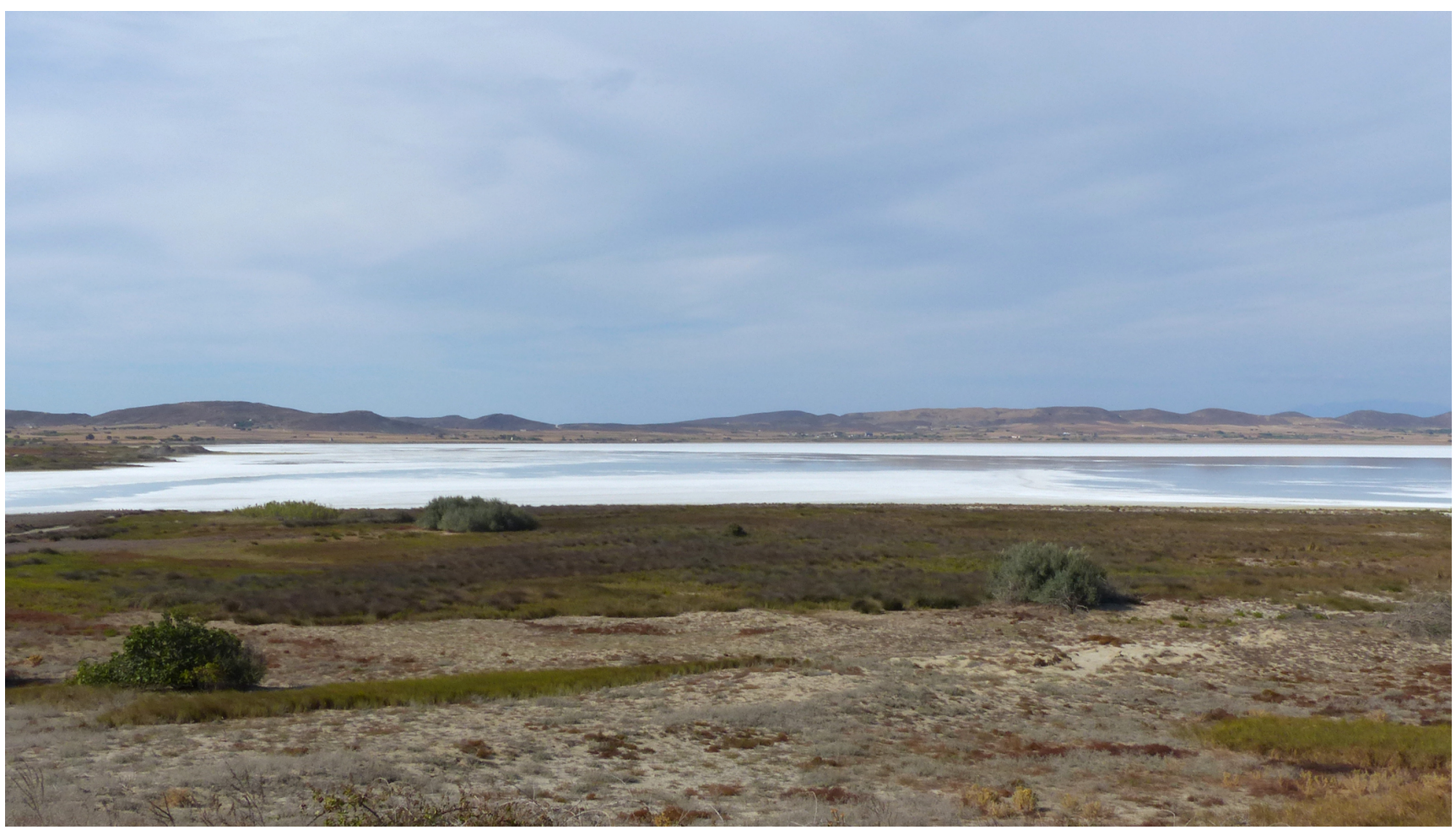

Fig. 7. [L11] South shore of Chortarolimni Lake, habitat of Pontia edusa. 


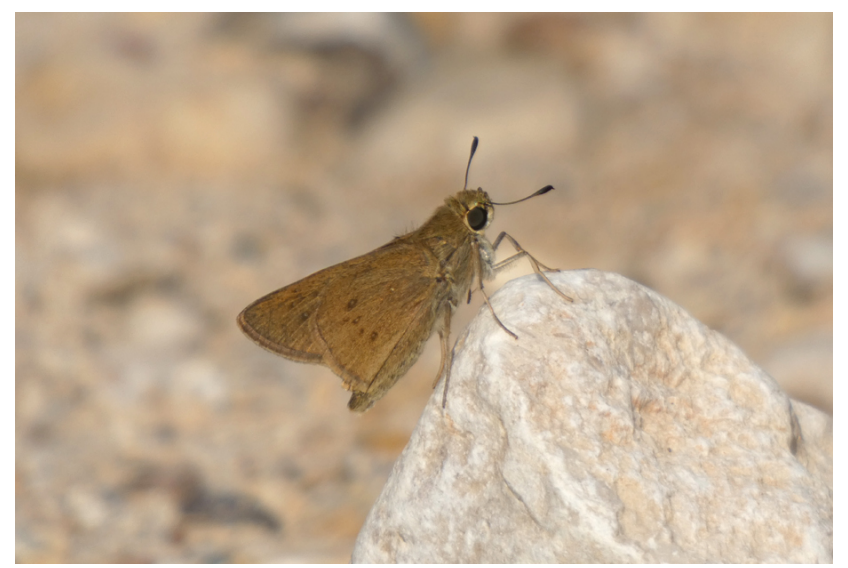

Fig. 8. Millet skipper Pelopidas thrax, male.

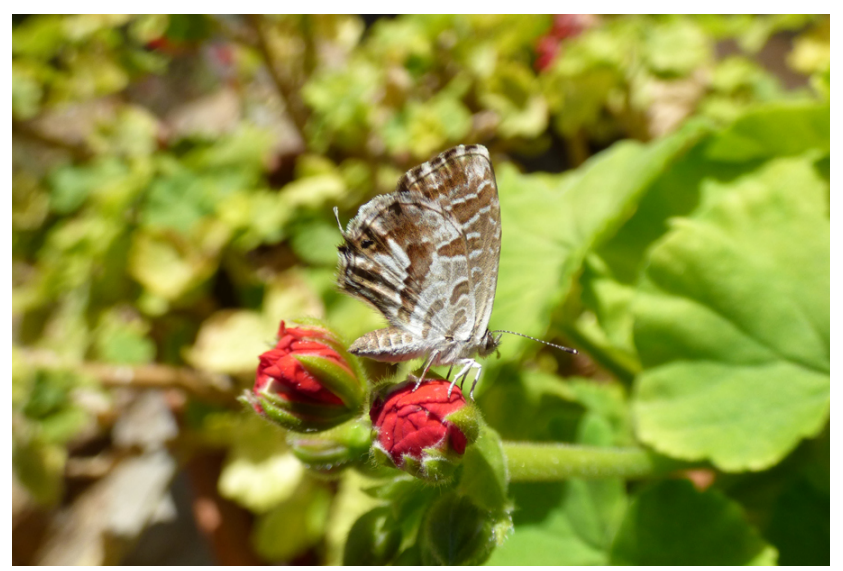

Fig. 10. Female of geranium bronze Cacyreus marshalli, ovipositing on Pelargonium.

to November, but all year round in some places, or in the tropics.

Gegenes nostrodamus (Fabricius, 1793): near Parthenomitos beach, 09.ix.2017 (Fig. 9).

Pieridae

Pontia edusa (Fabricius, 1777): S shore of Chortarolimni Lake, 01.ix.2016.

Lycaenidae

Lycaena phleas (Linnaeus, 1761): Ancient Poliochni, 01.ix.2016; near Skandali, 03.ix.2017; E of Lemnos Airport, 03.ix.2017; Parthenomitos, 09.ix.2017.

Lampides boeticus (Linnaeus, 1767): Ancient Poliochni, 01.ix.2016.

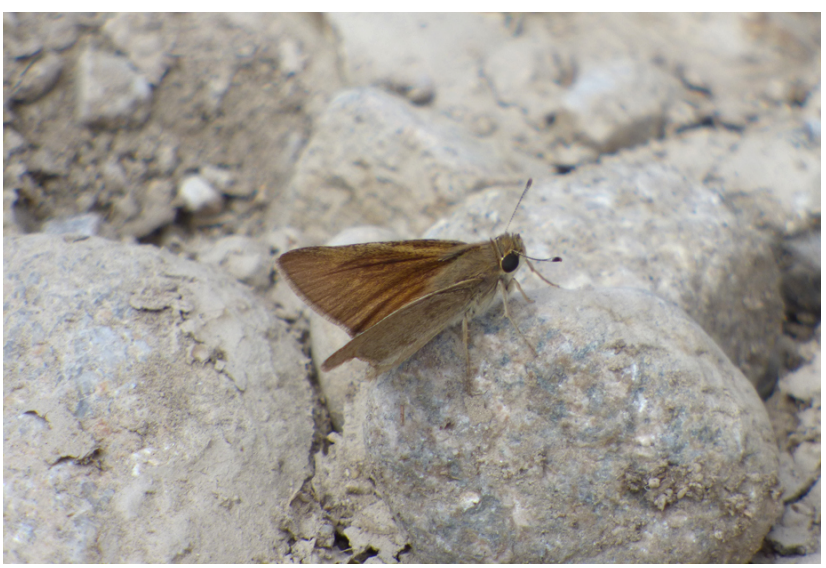

Fig. 9. Mediterranean skipper Gegenes nostrodamus, male.

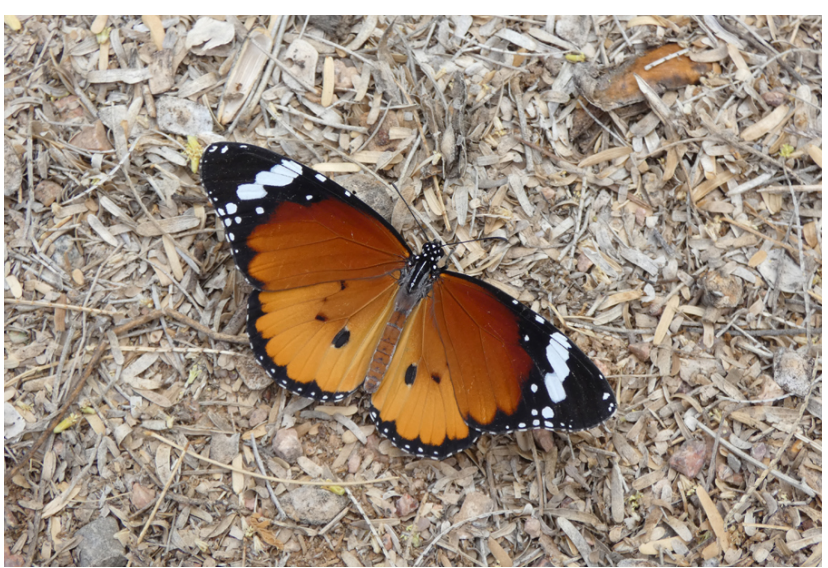

Fig. 11. Plain tiger Danaus chrysippus, male.

Leptotes pirithous (Linnaeus, 1767): Ancient Poliochni, 01.ix.2016.

Cacyreus marshalli Butler, 1898: Moudros, 27.viii.2016 (Fig. 10). It was introduced accidentally from South Africa to the European Mediterranean (initially in Majorca on the Balaeric Islands) in 1988, and in 1993 reached the European mainland, where it spreads further as a pest of cultivated Pelargonium. During the past 25 years, the butterfly has colonised much of North Africa and southern Europe and now is widespread in the Mediterranean region. In the eastern part of the Aegean Sea previously known from Dodecanese Islands and some of the North Aegean Islands (Samos, Fournoi, Chios, Lesbos) as well as the Turkish coast - Langourov \& Simov (2017). The species is multivoltine - on wing from March/April to November. 
Polyommatus icarus (Rottemburg, 1775): near Parthenomitos beach, 09.ix.2017.

Nymphalidae

Danaus chrysippus (Linnaeus, 1758): Parthenomitos beach, 09.ix.2017; Red Rock Beach, 07.ix.2019, 10.ix.2019. All specimens are flying from the sea towards north (Fig. 11). D. chrysippus is a polyvoltine, polyphagous wide-ranging migrant species. It is widespread in Asia, Africa and Australia and from the North African coastal regions it has colonised coastal areas of the Canary Islands and after 1970s and 1980s - along the N Mediterranean coast. Tennent $(1995,1996)$ indicated trends in the movement of the species range to the north, extending to NW Africa (Morocco, Algeria, Tunisia) and that the species uses resident populations to gradually extend its range further north to European countries (Morgun \& Ilyina, 2021). In the eastern part of the Aegean Sea, the species is previously known from some of the North Aegean Islands (Imbros [Gökçeada] - Okyar \& Aktaç (2006); Chios and Samos - Pamperis (2009); Lesbos - Martin \& Russell (2013) and some of the Dodecanese Islands (Astypalaia, Kos, Nisyros, Rhodes, Tilos, Symi) (Cuvelier \& Mølgaard, 2012; Galanos, 2017). The species is also known from the Turkish coast (Hesselbarth et al., 1995). The coincidence of this butterfly with Pelopidas thrax on some Aegean islands is discussed by Martin \& Russell (2013). Most of the observations in regions where the species does not form permanent populations (Cyprus, Greece, Turkey) are from September to November. All observed specimens showed typical migratory behaviour - flying towards north. The same pattern was recorded in Jordan, but earlier in the year (at beginning of April, near Aqaba, personal observations).

Maniola jurtina (Linnaeus, 1758): 30.viii.2016, Havouli beach; 05.ix.2016, near Myrina; near Parthenomitos beach, 09.ix.2017.

Vanessa atalanta (Linnaeus, 1758): Ancient Poliochni, 01.ix.2016.

Argynnis pandora ([Denis \& Schiffermüller], 1775): Ancient Poliochni, 01.ix.2016.

\section{References}

Coutsis J. 2001 Butterflies, Burnets and Harvesters from the Greek island of Límnos, a Skipper new to the Greek island of Santoríni and two Butterflies new to the Greek island of Síros (Lepidoptera: Hesperioidea, Papilionoidea, Zygaenidae). Phegea 29 (1): 9-17.

Cuvelier S. 2009 Skippers, Pelopidas thrax, a new species for the Island of Kós and an update of its distribution in Greece (Lepidoptera: Hesperioidea \& Papilionoidea). Phegea 37 (3): 84-93.

Cuvelier S., Mølgaard M.S. 2012 Butterflies and Skippers in the Dodecanese Islands (Greece): new data and an update on their distribution (Lepidoptera: Hesperioidea \& Papilionoidea). Phegea 40 (3): 66-80.

Galanos C. 2017 First record of Danaus chrysippus from the Island of Sími (Symi), SE Aegean, Greece (Lepidoptera: Nymphalidae, Danainae). Phegea 45 (1): 105-106.

Hesselbarth G., van Oorschot H., Wagener S. 1995 Die Tagfalter der Türkei, mit Berücksichtigung der angrenzenden Länder. Selbstverlag Sigbert Wagener, Bocholt, 3 volumes, 1-1354, 1-847, plates 1-141, maps I-IV, 1-342.

Langourov M., Simov N. 2017 New Data on the Expansion of the Geranium Bronze, Cacyreus marshalli Butler, 1898 (Lepidoptera, Lycaenidae) in the Eastern Part of the Balkan Peninsula, with Some Biological Notes. Acta zoologica bulgarica, Suppl. 9: 301-304.

Martin J., Russell P. 2013 Increasing numbers of records of Danaus chrysippus (Linnaeus, 1758) and Pelopidas thrax (Hübner, 1821) (Lepidoptera: Nymphalidae, Danainae; Hesperiidae) in the Eastern Aegean islands. Entomologist's Gazette 64 (2): 85-93.

Mathew G.F. 1898 Notes on Lepidoptera from the Mediterranean. Entomologist 31: 77-84, 108-116.

Morgun D.V., Ilyina E.V. 2021 The first record of Danaus chrysippus (Linnaeus, 1758) (Lepidoptera: Danaidae) in Russia in the context of the contemporary distribution of this species in the Western Palaearctic. Caucasian Entomological Bulletin 17 (1): 115-119.

Okyar Z., Aktaç N. 2006 Identification of Butterfly (Lepidoptera: Rhopalocera) fauna of Gökçeada and Bozcaada, Turkey. Pakistan Journal of Biological Sciences 9 (1): 76-79.

Olivier A. 1988 The butterflies of the Greek island of Límnos (Lepidoptera: Hesperioidea \& Papilionoidea). Phegea 16 (2): 33-42.

Pamperis L.N. 2009 The Butterflies of Greece. Second Edition. Editions Pamperis, Athens, 768 pp. 
Rebel H. 1934 Griechische Lepidopteren III Zeitschrift des Österreichischen Entomologischen Vereins 19: 55-56, 63-66.

Rebel H. 1937 Griechische Lepidopteren IV. Zeitschrift des Österreichischen Entomologischen Vereins 22: 63-67.

Tennent J. 1995 Danaus chrysippus Linnaeus, 1758; a review of records and present status in the Maghreb countries of Morocco, Algeria and Tunisia (Lepidoptera, Danainae). Nota lepidopterologica 17 (3/4): 201-216.
Tennent J. 1996 The butterflies of Morocco, Algeria and Tunisia. Gem Publishing Company, Wallingford, $218 \mathrm{pp}$.

Tshikolovets V.V. 2011 Butterflies of Europe \& the Mediterranean area. Tshikolovets Publications, Pardubice, 544 pp. 